\title{
問題提起 (1)
}

$$
\begin{array}{lllll}
\text { 座長 } & \text { 前 } & \text { 田 } & \text { 貞 } & \text { 亮 } \\
& \text { 沢 } & \text { 西 } & \text { 謙 } & \text { 次 }
\end{array}
$$

1. 透析頻度と社会経済 ( 2 週 5 回透析法のすすめ)

松下電器健保松下病病院腎不全センター 保井 明泰, 福田 豊史, 吉川 直德 門真クリニック 桑田 喜紀, 東 登伎雄, 松岡 敬祐

2. 残存腎機能のない患者は, すべて週 3 回透析が望ましいか? 一主として経済的な問題から一

\begin{tabular}{|c|c|}
\hline \multirow[t]{3}{*}{ 相模台病院腎センター } & $\begin{array}{l}\text { 桜井 健治，黒川 } \text { 純，藤井 } \\
\text { 知子 } \\
\text { 新上てずえ，伊藤：善一，塩月 }\end{array}$ \\
\hline & 河上 睦, 戸田 正代, 谷川み元子 \\
\hline & $\begin{array}{l}\text { 乙部 } \\
\text { 優子, 柏原千代子 } \\
\text { 絆, 小柴 健 }\end{array}$ \\
\hline
\end{tabular}

3. Dialysis minimum 敒関する考察

東京医科齒科大学第 2 内科 吉山 直樹, 中川成之輔, 末永 松彦 岩木 均, 佐々木, 成, 秋葉 隆 武内重五郎

4. 高令者透析について

\begin{tabular}{|c|c|c|c|c|}
\hline 国立王子病院内科 & 小出 & 桂三, 井上 & 昇, 森 & 一雄 \\
\hline & 遠山 & 純子，木村 & 正人, 池谷 & 満 \\
\hline & 林 & 勝憲 & & \\
\hline 東池袋内科医院 & 篠原 & 幸夫 & & \\
\hline
\end{tabular}

5. 透析医療の将来之家庭透析

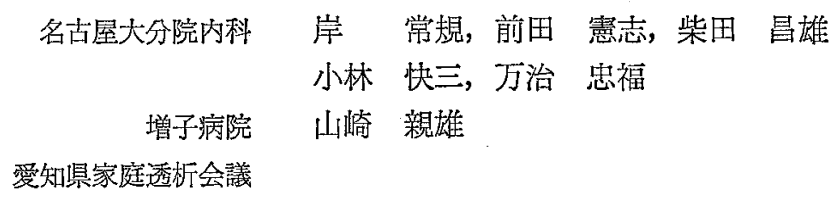

6. 透析医の研修システム化と透析療法の地域組織について一大学病院の透析室のあり方一 神戸大学第 2 内科 佐藤 笑一 